\title{
Metabolic Response
}

National Cancer Institute

\section{Source}

National Cancer Institute. Metabolic Response. NCI Thesaurus. Code C123623.

An evaluation of the metabolic response of the disease to the therapy. 